\title{
THE MINISTRY OF DEACONESSES IN BYZANTIUM AND PROJECTS FOR ITS RECONSTRUCTION AT THE PRE-COUNCIL CONFERENCE IN RUSSIA OF $1906^{1}$
}

\author{
Andrey V. Posternak \\ St. Tikhon's Orthodox University, Moscow, Russian Federation
}

\begin{abstract}
Introduction. The order of deaconesses in Byzantium was formed by the time of the Council of Chalcedon in 451. The idea of the institutionalization of the women's ministry was revived in the new conditions in Russia of the $19^{\text {th }}$ - early $20^{\text {th }}$ century because of the need for Church reforms. Materials and methods. A comparative analysis of the ancient order of deaconesses and the project of its reconstruction in Russia allows us to determine characteristics of the ministry and status of deaconesses that depended on the specific living conditions of the Church. The deaconesses in the Byzantine Empire were ministers of the Church: the bishop ordained widows or virgins between the ages of 40 and 60 . Deaconesses kept chastity, had property rights, were assigned to a parish, helped priests at the baptism of women, and were subordinate to clergymen. By the $12^{\text {th }}$ century, the female order in Byzantium disappeared, however the honorary title of deaconess could later be worn by the prioress of female monasteries. The Russian Church has never had deaconesses, but in the $19^{\text {th }}-$ early $20^{\text {th }}$ century projects were discussed for the reconstruction of this women's ministry which was actively developing in the protestant tradition. The Pre-Council Conference in 1906 developed a draft of Church reforms, including the rules for orthodox deaconesses, who could be elected from active parishioners, not nuns. It was assumed that these women were supposed to keep order in the Church, help the priest in the parish, at the baptism and catechumenate of women, help the sick and the needy, in the so called "inner mission". However, the undeveloped status of deaconesses as new ministers of the Church did not allow this project to be implemented. Results. The order of the deaconesses that disappeared in Byzantium and the attempt to restore it in Russia show that a stable institutionalization of women's ministry took place only at a certain period in the history of the Church which needed it.

Key words: deaconesses, women's ministry, Byzantine Orthodoxy, Russian Orthodox Church, Pre-Council Conference in 1906, "inner mission".

Citation. Posternak A.V. The Ministry of Deaconesses in Byzantium and Projects for Its Reconstruction at the Pre-Council Conference in Russia of 1906. Vestnik Volgogradskogo gosudarstvennogo universiteta. Seriya 4. Istoriya. Regionovedenie. Mezhdunarodnye otnosheniya [Science Journal of Volgograd State University. History. Area Studies. International Relations], 2021, vol. 26, no. 6, pp. 352-364. (in Russian). DOI: https://doi.org/10.15688/jvolsu4.2021.6.26
\end{abstract}

УДК 94(451)+27

Дата поступления статьи: 29.04.2020

ББК $63.3(0) 4$

Дата принятия статьи: 12.04.2021

\section{СЛУЖЕНИЕ ДИАКОНИСС В ВИЗАНТИИ И ПРОЕКТЫ ЕГО ВОССТАНОВЛЕНИЯ НА ПРЕДСОБОРНОМ ПРИСУТСТВИИ В РОССИИ 1906 ГОДА ${ }^{1}$}

\section{Андрей Владимирович Постернак}

Православный Свято-Тихоновский гуманитарный университет, г. Москва, Российская Федерация

Аннотация. Институт диаконисс в Византии сложился к эпохе Халкидонского собора 451 года. Идея институализированного женского служения возродилась в новых условиях в России ХІХ - начала XX в. в связи с необходимостью церковных реформ. Сравнительный анализ древнего чина диаконисс и проекта его восстановления в России позволяет выделить характеристики служения и статуса диаконисс, зависевшие от 
конкретных условий жизни Церкви. Диакониссы в Византии были церковнослужительницами: епископ посвящал вдов или дев через рукоположение в возрасте от 40 до 60 лет. Диакониссы хранили целомудрие, обладали имущественными правами, прикреплялись к приходским храмам, помогали священникам при крещении женщин, подчинялись клирикам-мужчинам. К ХІІ в. женский чин в Византии перестал существовать, однако почетное звание диаконисс могли носить руководительницы женских монастырей. В Русской Церкви диаконисс никогда не было, но в XIX - начале XX в. обсуждались проекты возрождения этого женского служения, которое активно развивалось в западной протестантской традиции. На Предсоборном присутствии 1906 г. был подготовлен проект церковных реформ, были составлены правила для православных диаконисс, которые могли избираться из активных прихожанок, не монахинь. Предполагалось, что служительницы будут следить за порядком в храме, помогать священнику на приходе, в том числе при крещении и катехизации женщин, помощи больным и нуждающимся - в так называемой «внутренней миссии». Однако данный проект так и не будет реализован. Исчезнувший в Византии чин диаконисс и попытка его восстановления в России показывают, что устойчивая институализация женского служения произошла лишь в определенный период существования Церкви, имевшей в этом потребность.

Ключевые слова: диакониссы, женское служение, Византийское православие, Русская Православная Церковь, Предсоборное присутствие 1906 г., «внутренняя миссия».

Цитирование. Постернак А. В. Служение диаконисс в Византии и проекты его восстановления на Предсоборном присутствии в России 1906 года // Вестник Волгоградского государственного университета. Серия 4, История. Регионоведение. Международные отношения. - 2021. - Т. 26, № 6. - С. 352-364. DOI: https://doi.org/10.15688/jvolsu4.2021.6.26

Введение. Служение диаконисс в Древней Церкви и византийский период отражало потребности внутрицерковной жизни, связанной с необходимостью оказывать помощь женщинам, принимающим крещение, или христианкам, членам общин. Оно зависело от местных условий, но постепенно необходимость в этом женском чине для Церкви отпала, и уже после VII в. он исчез. Однако идея институализированного женского служения, претерпевая трансформацию, возрождалась в новых условиях. В России соответствующие предпосылки возникли в XIX в., в период активного развития благотворительности, «внутренней» (то есть нацеленной на благотворительную помощь обездоленным и нуждающимся внутри страны) и «внешней» (нацеленной на катехизацию и обращение в православную веру малых народов империи, сохранявших языческий уклад жизни) миссии после эпохи Великих реформ - именно тогда вопрос о возобновлении служения диаконисс стал актуальным.

Методы. Служение древних диаконисс и попытка восстановления данного чина в России к началу XX в. отражают глубинные изменения внутри Церкви и общества, которые можно рассматривать как универсальные, а на примере сравнения двух форм служения можно вычленить общие характеристики служения и статуса диаконисс, зависевшие от конкретных условий жизни Церкви, что и является предметом данной статьи. В современной научной литературе при колоссальном количестве исследований, посвященных разным аспектам церковной деятельности женщин, в частности диаконисс, в восточной и западной частях Древней Церкви (см. составленные нами обзор научной литературы и библиографию в кн.: [14, с. 14-22, 487-518]), достаточно мало специальных работ именно о служении диаконисс в Византии, начиная с IV века. В отдельных статьях и главах монографий рассмотрены или конкретные примеры известных и знатных диаконисс [35] или отдельные аспекты их служения [27], роль в литургической жизни [28], местонахождение и функционал в храме [16, с. 150-162], в том числе в св. Софии [40]. Однако служение диаконисс важно охарактеризовать с помощью историко-критического метода на основании имеющихся источников византийского времени как институциональное в период его расцвета и как модель, на которую будут ориентироваться как на эталон для восстановления данного служения члены Предсоборного присутствия 1906 г., материалы которого являются основой для анализа восстанавливаемого чина диаконисс в Православной Церкви в России.

Анализ. В ранневизантийский период, к эпохе Халкидонского собора 451 г., статус диаконисс уже оформился. Можно определен- 
но говорить о сложившемся функционале этих женщин по таким более ранним памятникам, как «Дидаскалия» (III в.) и «Апостольские постановления» (IV в.). В диакониссы могла избираться дева или вдова, бывшая один раз замужем [29, vol. 2, p. 348 (Const. ap. VI.17.4)]. В «Апостольских постановлениях» сохранилась молитва епископа на посвящение диакониссы [29, vol. 3, p. 220, 222 (Const. ap. VIII.19$20)$ ], которое совершалось им через возложение рук [29, vol. 2, p. 146 (Const. ap. III.11.3)]. Во время крещения женщин диаконисса, помогая епископу, помазывавшему елеем лишь голову крещаемой, для соблюдения приличия помазывала остальные части тела и могла затем воспринимать ее из купели и наставлять в вере [29, vol. 2, p. 156, 158 (Const. ap. III.16.2-4); vol. 3, p. 230 (Const. ap. VIII.28.6); 28, vol. 1, p. 208, 210 (Did. III.12.2-4)]. Диакониссы стояли у женского входа в храм, очевидно, там, где существовало разделение на женские и мужские половины [29, vol. 1, p. 314 (Const. ap. II.57.10); vol. 3, p. 230 (Const. ap. VIII.28.6)]; посещали дома христианок, живших в языческом окружении, куда невозможно было направить мужчину-клирика [26, vol. 1, p. 208, 210 (Did. III.12.1,4); 29, vol. 2, p. 154,$156 ; 160$ (Const. ap. III.16.1; 19.1)], чтобы помочь им во время болезни [26, vol. 1, p. 210 (Did. III.12.4)]. Диакониссы, очевидно в силу своего статуса, причащались первыми среди женщин [29, vol. 3, p. 210 (Const. ap. VIII.13.14)]. До конца непонятно, насколько повсеместным было это служение, однако уже 15-й канон Халкидонского собора предписывал «в диакониссы поставлять женщину возрастом не моложе сорока лет» [42, б. 3] (рус. пер. цит. по: [12, с. 369]). Такая практика сохранялась и позднее, в VI-VII вв., что подтверждают 123-я новелла Юстиниана (546 г.) [25, Nov. 123.13], а также 14-й и 40-й каноны Трулльского собора 691-692 гг. [41, б. 11-12], и даже поздневизантийский комментатор Матфей Властарь в «Алфавитной синтагме» (XIV в.), созданной после исчезновения женского служения [23, col. 1171, 1173]. Сорокалетний возраст рассматривался в 40-м каноне Трулльского собора [41, б. 11-12] как установленный «священными правилами», то есть, скорее всего, вышеупомянутым 15-м правилом Халкидонского собора, и, с одной сторо- ны, как отступление от канонов святителя Василия Великого, считавшего, что монахиней могла становиться девица, достигшая совершеннолетия в 16 или 17 лет [34, p. 158, Bas. Magn. Ep. (191) 199 ad Amph., can. 18], a c другой - как отступление от предписания апостола Павла из Первого послания к Тимофею об избрании вдов не менее как шестидесятилетних (1 Тим. 5. 3-16). Последний тезис подтверждает и 2-я конституция 16-й книги Кодекса Феодосия (390 г.), устанавливавшая для диаконисс 60-летний возраст «согласно предписанию апостола» [36, Cod. Theodos. 16.2.27 pr.] (рус. пер. С.А. Емельяновой цит. по: [15, c. 119]); по 6-й новелле Юстиниана он «не должен быть юным или преклонным... быть старше средних лет и приближаться к пятидесяти годам»: более молодая женщина могла рукополагаться только в монашеской обители [25, Nov. 6.6] (рус. пер. К.А. Максимовича цит. по: $[10$, с. 39]). 50-летний возраст предписывал диакониссам Афанасий Схоластик [19, Athanas. Schol. Nov. const. (19)1.1.9], во всяком случае не менее 40 лет [19, Athanas. Schol. Nov. const. (32)1.2.25]. Таким образом, в византийской традиции минимальные возрастные границы для рукополагаемых женщин устанавливались в диапазоне от 40 до 60 лет. Их канонические обоснования возводились к апостольской эпохе и рассматривались либо как указания апостола Павла вдовам, служение которых отождествлялось со служением диаконисс (что на самом деле является поздним толкованием слов апостола), либо как отступление от этого правила.

Как происходило рукоположение диаконисс в ранневизантийский период неизвестно. Наиболее полное чинопоследование сохранилось лишь в рукописи Барберини (не ранее 787 г.), византийском литургическом памятнике Южной Италии [5, с. 31, 172-173, 384-386, Euchologion. 163-164], когда в Восточных Церквах женский диаконат уже перестал существовать. Впрочем, рукопись могла отражать литургическую практику, восходившую и к V в. [39, p. 27-31]. По косвенным, но достаточно убедительным данным можно утверждать, что рукоположение происходило в алтаpe. В частности, оно, как и хиротония диакона, начиналось после Анафоры перед ектеньей «Вся святыя помянувше...», то есть во вре- 
мя Литургии, когда рукополагаемая подводилась к архиерею, и маловероятно, что ради посвящения диакониссы епископ перед причастием специально покидал алтарь - этот факт как исключительный нашел бы отражение в чинопоследовании, в общих чертах сходном с рукоположением диакона. В той же рукописи Барберини в конце описания чинопоследования рукоположения диакона сказано, что оно, как и хиротония диакониссы ( $\tau \tilde{\eta}_{\varsigma} \delta 1 \alpha \kappa o v i ́ \sigma \sigma \eta \varsigma$ $\chi \varepsilon i \rho o \tau o v i ́ \alpha v)$, должно происходить на полной Литургии или Литургии Преждеосвященных Даров [5, с. 171, Euchologion. 162.14]. Опять же при внеалтарном посвящении, которое может происходить в любой момент богослужения, данная оговорка не имела бы смысла. В конце чинопоследования указано, что «после того, как она причастилась Святого Тела и Пречистой Крови, архиепископ дает ей святую чашу, которую она принимает и поставляет на святую трапезу» [5, с. 386, Euchologion. 164.13] (рус. пер. С. Голованова цит. по: [5, c. 173]). Очевидно, что причастие диакониссы в таком случае происходило в алтаре. Матфей Властарь, хотя и гораздо позднее, чем сложился чин рукописи Барберини, свидетельствовал: «Другие говорят, что им [диакониссам. $-A$. П.] позволялось входить и в святой алтарь и проходить служение, подобное служению диаконов ( $\tau \grave{\alpha} \tau \tilde{\omega} v \delta 1 \alpha \kappa o ́ v \omega v ~ \alpha ̊ v \delta \rho \tilde{\omega} v$

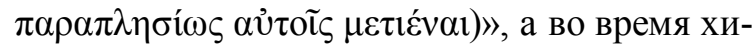
ротонии диаконисса «приводится к священно-

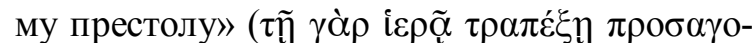
$\mu \varepsilon ́ v \eta v)[23$, col. 1173, Matth. Blast. Synt. alph. $\Gamma$, cap. 11] (рус. пер. Н. Ильинского цит. по: [15, c. 169]). Ему вторил другой византийский канонист Феодор Вальсамон, что «некогда чин диаконисс признавался в канонах, и у них [диаконисс] было [определенное] положение в

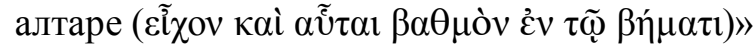
[21, col. 988; Theod. Bals. Resp. ad interrog. Marci. 35] (pyc. пер. А.В. Постернака цит. по: $[15$, с. 164]). Таким образом, скорее всего, в алтаре во время Литургии женщина подводилась к архиерею, не вставала на колени, а только наклоняла голову, на которую епископ клал руку и читал молитвы, осеняя ее крестным знамением. Епископ брал диаконский орарь и надевал его на шею диакониссы двумя концами вперед под особый, напоминающий монашескую одежду, мафорий, после чего, как ска- зано выше, диаконисса причащалась. Основываясь на особенностях посвящения диаконисс (нахождение в алтаре, читаемые архиереем молитвы, определенное сходство чинопоследований диакона и диакониссы, возможность касаться женщинам священных сосудов, ношение диаконского ораря), можно высказать осторожное предположение, что положение диаконисс сильно сближалось с положением диаконов. Матфей Властарь, комментируя посвящение диаконисс, кратко подтверждал основные моменты рукоположения диакониссы по рукописи Барберини: что она не становится на колени, а лишь нагибает голову, когда архиерей читает молитву, возлагает на нее диаконский орарь двумя концами вперед, после чего она «причащается Божественных Таин после диаконов и, приняв чашу из рук архиерея, никому не преподает, но тотчас ставит ее на святую трапезу [престол] ( $\dot{\alpha} \lambda \lambda^{\circ}$

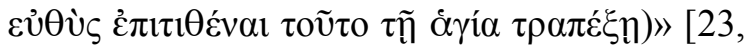
col. 1176, Matth. Blast. Synt. alph. Г, cap. 11] (рус. пер. Н. Ильинского цит. по: [15, с. 310]). Властарь утверждал, что епископ «отнюдь не дозволяет ей служить при Пречистых Тайнах или брать в руки рипиды, подобно диакону», однако при этом сообщал «об обязанностях [диаконисс. - A. П.], которые те же, что и у диаконов, кроме немногого» ( $\pi \lambda \grave{\eta} \nu$ ỏ $\lambda \dot{\gamma} \gamma \omega v$, ö $\sigma \alpha$

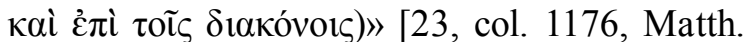
Blast. Synt. alph. Г, cap. 11] (рус. пер. Н. Ильинского цит. по: [15, с. 310$])$. Что имел в виду под последним Властарь, трудно прокомментировать, однако он явно сближает функционал диаконисс и диаконов.

Диакониссы, как и любые штатные клирики, по практике, сохранившейся для клириков до нынешних дней, прикреплялись к определенным храмам или монастырям, где согласно специальному статуту полагалось иметь их определенное число, например, в константинопольской Софии согласно 3-й новелле императора Юстиниана - не более сорока [25, Nov. 3.1], то же подтверждают патриарх Фотий (820-896) со ссылкой на указ императора Ираклия I (610-641) [31, col. 556, Phot. Synt. can. I.30] и «Василики», в комментариях к которым уточнялось, что эти сорок диаконисс, помимо Софии, должны были служить еще в трех городских храмах [22, Basilica. III.2.1]. В житии св. Олимпиады, отражавшем 


\section{ВИЗАНТИЙСКОЕ ПРАВОСЛАВИЕ}

исторический контекст более позднего, чем $\mathrm{V}$ в., времени (создано анонимным автором и сохранилось в «Парижском» и «Флорентийском» кодексах XI и XIV вв.), сообщается, чтобы монастырь, где эта святая была посвящена, «всегда имел четыре диаконских места

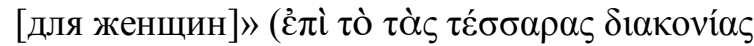

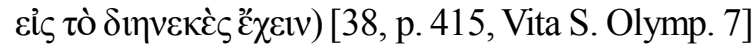
(рус. пер. А.В. Постернака цит. по: [15, с. 275]). Диакониссы могли обладать защищенным Церковью имуществом, которое никто не мог у них отторгнуть, пересмотрев условия дарения, наследства или другой сделки, по которой они его получили [25, Nov. 123.37]. Впрочем, эта защита упразднялась в случае серьезной провинности диакониссы, связанной с нарушением целомудрия: виновная ссылалась в монастырь, а ее имущество распределялось между ее детьми (если таковые были), приходским храмом, где она служила, и монастырем, куда отправлялась [25, Nov. 123.30], эти же требования повторят позднее «Расширенный Прохирон» [32, Prochir. auct. 28. 71] и Матфей Властарь [23, col. 1173, Matth. Blast. Synt. alph. $\Gamma$, cap. 11]).

В диакониссы могла посвящаться женщина, не только обладавшая имуществом, но и высокого происхождения, о чем свидетельствуют примеры св. Олимпиады, а также сестры (ее имя осталось неизвестным) патриарха Кириака II (592-606), в память о которой одно из мест Константинополя, по свидетельству Псевдо-Кодина (XV в.), получило название «Угодья диакониссы», имевшее хождение как минимум до X в.: «“Угодья Диакониссы” основал патриарх Кириак во времена царя Маврикия [582-602. - А. П.], его сына [Тиберия, 590-602. - А. П.], и так было названо данное место, потому что патриарх, будучи диаконом, там жил, - но и сестра того самого патриарха, диаконисса, пребывала там» (T⿳亠丷⿵

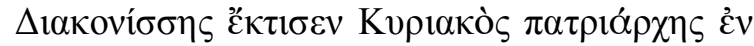

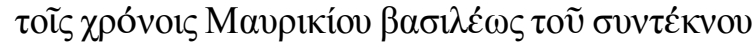

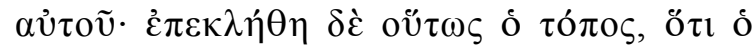

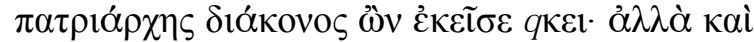

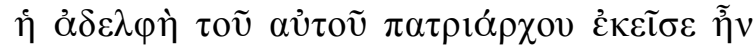
$\delta 1 \alpha \kappa o ́ v 1 \sigma \sigma \alpha)$ [33, p. 250, Ps.-Codin. Patr. Constant. III.102] (pус. пер. С.А. Емельяновой цит. по: [15, с. 164]). После смерти приходской диакониссы храм мог также претендовать на ее имущество $[36$, Cod. Theodos. 5.3.1; 27,
Nov. 123.13]. Диаконисса, как и остальные клирики, находилась в подчинении у епископа, который сначала получал извещение от истца в случае имущественной претензии женщине, а потом разбирал саму тяжбу [25, Nov. 123.21].

Диакониссы должны были, как и в более ранний период, «прислуживать при досточтимых крещальных чинах и помогать при прочих неизреченных [священнодействиях], которые обычно совершаются с их участием во время святых таинств» [25, Nov. 6.6] (рус. пер. К.А. Максимовича цит. по: [10, с. 39]). По сути, на это же указывал и Иоанн Мосх в «Луге духовном» в случае с иерусалимским архиепископом Петром (524-546/550), который из-за смущения старца Конона крестить взрослую женщину хотел избрать диакониссу [30, col. 2853, Mosch. Iohan. Prat. spirit. 3]. Диакониссы являлись участницами богослужений, на которых присутствовал император. В частности, Константин VII Багрянородный (913959), описывая выход и шествие императора через святую Софию накануне Пасхи, в день Великой Субботы, упоминает их стоящими в

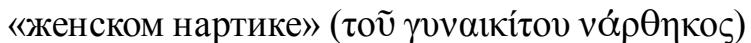
[24, Const. Porph. De cerimon. I.171]. Д.Ф. Беляев обоснованно считал, что речь идет о «гинеконите» - северном нижнем нефе храма св. Софии, добавляя при этом, что женщины могли занимать верхние западные и северные галереи («катехумении») над левым нефом и, соответственно, над нартиком [1, с. 142-145]. По мнению Р. Тафта, «гинекеем» (вышеназванным, по Д. Беляеву, «гинеконитом»), или «катехумениями», назывались галереи, окаймлявшие храм с трех сторон (кроме восточной) $[16$, с. 94, 141]).

Диакониссам предписывалось обязательное хранение целомудрия, они часто упоминаются в «Новеллах» наряду с монахинями и отшельницами «и сами могли быть монахинями» [25, Nov. 123.21, 28, 37]. Соблазнение диакониссы приравнивалось к уголовному преступлению, как и против постницы-монахини [25, Nov. 123.43], а добровольно нарушавшая чистоту отстранялась от служения и ссылалась в монастырь [25, Nov. 123.30].

Первые указания на то, что чин диаконисс в Византии, по крайней мере, в области Иерусалима, был упразднен, относятся к VI в., то есть уже ко времени складывания корпуса 
новелл Юстиниана. В «Луге духовном» Иоанн Mocx в начале VII в. сообщал как о недавнем событии о вышеприведенной истории с иерусалимским архиепископом Петром, который во избежание искушений старца Конона хотел для помощи ему при крещении женщин посвятить диакониссу, «но не сделал этого, потому

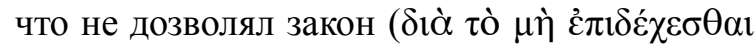

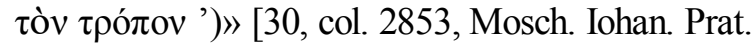
spirit. 3] (рус. пер. М.И. Хитрова цит. по: [8, с. 7]). Византийский знаток церковного права Феодор Вальсамон в комментарии на 15-й канон Халкидонского Собора свидетельствовал, что к его времени (XII в.) «то, [о чем говорится] в данном правиле, совсем исчезло. Теперь диакониссы не рукополагаются, хотя некоторых отшельниц и называют неправильным словом “диакониссы”». [20, col. 441; Theod. Balsam. Comm. in can. 15 Conc. Chalc.] (pyc. пер. А.В. Постернака цит. по: [15, с. 132]). Вальсамон в другом трактате ссылался на то, что чин диаконисс прекратил свое существование еще потому, что молодым женщинам из-за месячных очищений было запрещено входить в алтарь [13, col. 988; Theod. Bals. Resp. ad interrog. Marci. 35]. Об этом же писал и Матфей Властарь [23, col. 1173, Matth. Blast. Synt. alph. Г, сар. 11]. Очевидно, к этому времени давно ушла в прошлое практика крещения взрослых женщин и Церковь уже не нуждалась в других специфических функциях диаконисс, а канонисты пытались объяснить отсутствие диаконисс физиологическими особенностями женщин, которые в более раннюю эпоху не являлись препятствием для посвящения служительниц у престола.

Термин диаконисса в византийской традиции XIII-XIV вв. мог использоваться не только применительно к монахиням, но и в отношении женщин-руководительниц женских монастырей: именно так именуются настоятельница и келарница (заведующая хозяйством) в типиконе константинопольского монастыря Божией Матери «Твердое упование» [37, p. 57 (XI.68), p. 57-58 (XII.69), p. 73 (XIX.97)], о чем свидетельствовали отдельные подзаголовки устава, например: «Какая диаконисса [должна быть] также заведующей келарием [монастырской кладовой] и в чем

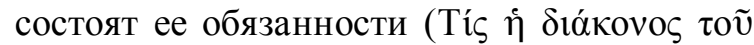

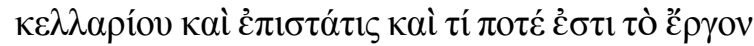

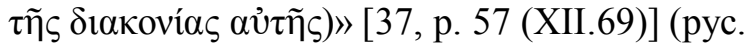
пер. А.В. Постернака цит. по: [15, с. 166]). На Западе к этому времени уже имело место сходное словоупотребление, когда аббатисс могли именовать диакониссами, что встречается в письмах Пьера Абеляра к Элоизе: «Полагаем необходимым и достаточным для полного управления монастырем семи жен из вашей среды: келарницу, ризничную, ухаживающую за больными, певчую, алтарницу и наконец диакониссу, которую теперь называют аббатиссой (et ad extremum diaconissam, quam nunc abbatissam nominant)» [18, p. 164, Abael. Ep. ad Heloiss. 8] (pyc. пер. А.В. Постернака цит. по: [15, с. 224]).

В Русской Православной Церкви, несмотря на тесную связь с византийской традицией, диаконисс никогда не было. Идеи по привлечению новых «служительниц», диаконисс, к миссионерской деятельности высказывали архимандрит Макарий (Глухарев) [9, c. 99-122] и епископ Николай Японский (Касаткин) $[11$, с. 311,373$]$ в контексте развития миссионерской деятельности среди инородцев, свящ. Александр Гумилевский предлагал разработать устав диаконисс для активизации именно приходской церковной жизни в противовес деятельности сестер милосердия [13, стб. 141-166, 177-182]. Однако первым опытом реального обсуждения чина диаконисс в Русской Церкви стало Предсоборное присутствие 1906 г., созванное по указу императора Николая II с целью разработать законодательную базу для Церкви в новых послереволюционных условиях и в конечном счете подготовить Поместный собор, чтобы изменить управление всей Церковью.

Вопрос о диакониссах обсуждался в IV отделе присутствия, занимавшемся вопросами приходской жизни, его история освещена в некоторых работах $[17$, с. $328-334 ; 3$, c. 348-353], в одной из которых даже делалось обобщение, что еще до начала работы присутствия в Русской Церкви было выработано 2 модели восстановления диаконисс как монашествующих и приходских [17, с. 333]. И особый интерес представляет сравнение этого проекта с известными фактами о служении диаконисс в Византии. Уже на заседании 21 марта была впервые озвучена идея важности восстановления чина диаконисс, осо- 


\section{ВИЗАНТИЙСКОЕ ПРАВОСЛАВИЕ}

бенно там, где есть благотворительные женские общества [7, т. 1, с. 797-798]. 19 апреля протоиерей А. Заозерский в контексте обсуждения вопроса об избрании женщин в приходские советы вспомнил о древних диаконисcax, у которых был высокий статус, напомнив, что по Матфею Властарю они причащались, беря в руки чашу, и подчеркнул, что женщина ныне устранена от церковного служения, но в вопросах служения бедным и больным всегда играла исключительную роль [7, т. 1, с. 800$]$.

Протоиерей А. Мальцев в докладе «Внутренняя миссия», приложенном к журналу № 5 от 20 апреля [7, т. 1, с. 809-816], продвигал идеи о необходимости развития активной социальной помощи (уход за больными, помощь нуждающимся) людям со стороны Церкви, в которой, по его словам, в древности уже существовал такой опыт деятельности диаконисс, занимавшихся именно широкой благотворительностью. Такого рода церковная деятельность в рамках протестантских деноминаций, по словам А. Мальцева, получила наименование «внутренняя миссия», крайне необходимая и для России. Таким образом, докладчик, по сути, отождествлял основные цели деятельности современных ему уже существовавших протестантских и древних диаконисс. Более того, для него включение женщин в активную помощь нуждавшимся было непременным условием возрождения и приходской церковной жизни в России $[7$, т. 1 , c. $810-811,816]$.

K 5 июля 1906 г. IV Отдел утвердил окончательный проект Нормального устава православных приходов России [7, т. 1, с. 852], согласно 12 статье которого девиц и вдов не младше 40 лет православного вероисповедания, занимавшихся церковной деятельностью на приходе, епископ мог посвятить в диакониссы [7, т. 1 , с. 859 ; т. 2, с. 1066]. По инструкции, разработанной для настоятелей церквей, этому должно было предшествовать предварительное ходатайство настоятеля храма, особенно в тех местах, где сильно сектантское или старообрядческое влияние, то есть подчеркивалась важность катехизаторских функций женщин [7, т. 1 , с. 871]. Появление диаконисс, по мысли составителей документа, было необходимо и «для возвышения нравственно-просветительного воздействия духовенства на паству» $[7$, т. 2 , с. 914 ; т. 3 , с. 665$]$.

К 12 параграфу «Проекта Нормального устава» прилагался «Проект правил жизни и деятельности православных диаконисс» [7, т. 1, с. 877-879], который постатейно предусматривал следующее. Диакониссами могли стать православные христианки, желавшие послужить Церкви, посвященные на это служение архиереем [7, т. 1, с. 877], причислявшиеся к клиру [7, т. 1, с. 877]. Их функционал состоял в заботе о церковных облачениях и утвари, чистоте и общем благолепии в храме. Для уборки алтаря диакониссам разрешалось входить в алтарь, но без права касаться жертвенника и престола [7, т. 1, с. 877]. Во время богослужения диакониссы должны следить за общим порядком, поведением женщин и детей, помогать при причастии младенцев и крещении взрослых женщин [7, т. 1, с. 877]. Диакониссы, будучи соответственно подготовленными, должны катехизировать женщин, готовящихся к крещению [7, т. 1, с. 877], помогать священнику и приходскому совету в заботе о сиротах и в делах благотворительности (изыскивать средства, посещать больных, трудиться при богадельнях, если таковые имелись при приходах) [7, т. 1, с. 877]. Диаконисы должны присутствовать на всех приходских богослужениях, выполнять положенное молитвенное правило, читать Евангелие и Псалтирь дома, если не было возможности посетить службу [7, т. 1, с. 877]. Служительницы должны причащаться в великие праздники, но не менее четырех раз в год, вести строгую благочестивую жизнь [7, т. 1, с. 877]; должны носить скромную одежду, а по благословению епископа - даже наподобие монашеской $[7$, т. 1 , c. 878]. В диакониссы посвящаются вдовы и девы в возрасте не менее сорока лет. Епископ совершает посвящение с возложением диаконского ораря во время Литургии, на малом входе (как и диакона), с чтением древней молитвы, или вне Литургии, во время молебна по особому чинопоследованию (в примечании дана ссылка на рукопись Барберини) [7, т. 1, с. 878-879]. Вдовы и девы младше сорока лет могли быть допущены к новому служению в звании церковниц без посвящения и права входить в алтарь [7, т. 1, с. 879]. Труды 
диаконисс признавались безвозмездными, но в старости женщины имели право на призрение от прихода [7, т. 1, с. 879]. Если при храме имелись «кружки сестер» (собрания благочестивых прихожанок), они могли объединяться вокруг диаконисс и становиться подготовительной ступенью к новому женскому званию [7, т. 1, с. 884].

На заседаниях 2 и 5 декабря к приходскому уставу свои замечания высказал Л.А. Тихомиров, подчеркнув, что диакониссы должны стать членами приходского собрания [7, т. 3, с. 655]. Епископ Могилевский Стефан (Архангельский), в свою очередь, предложил докладную записку игуменьи Леснинского монастыря Холмской епархии Екатерины (Ефимовской) о восстановлении чина диаконисс и рапорт епископа Холмского Евлогия (Георгиевского) по этому поводу. Игуменья Екатерина считала необходимым основание при Леснинской обители общины диаконисс с миссионерскими целями, а для их подготовки - училища богословия, поддержанного благотворителями, куда могли поступать девицы и вдовы со средним общим образованием. Епископ Евлогий как правящий архиерей епархии Леснинского монастыря, принципиально не возражая против нового чина, указывал на то, что в древности он существовал очень недолго, а это ключ к пониманию новой проблемы женского служения, которое исчезло не из-за отсутствия надобности, а из-за сокращения числа лиц, готовых посвятить себя новому служению, и из-за того, что сами диакониссы «оказывались не на высоте своего призвания» (впрочем, данный аргумент не был никак подтвержден), а сейчас потребуется очень много диаконисс и возникнет проблема регулирования их отношений с настоятелем и приходом [7, т. 3, с. 657], чтобы женщины не ушли в оппозицию применительно к другим клирикам. По мнению епископа Евлогия, посвящение диаконисс не должен совершать архиерей, то есть «в настоящее время желательно восстановление служения, а не чина диаконисс» [7, т. 3, с. 658]. Протоиерей Ф. Успенский сделал замечания на проект игуменьи Екатерины и отзыв епископа Евлогия, главным из которых было то, что IV отдел ставил перед собой задачу возродить приходское служение диаконисс, которыми будут местные прихожан- ки, а не женщины со стороны, и к их подбору надо тщательно относиться [7, т. 3, с. 658]. Н.Д. Кузнецов добавил, что на первых порах необходим «рассадник для их надлежащего подготовления», которым и могла быть Леснинская обитель [7, т. 3, с. 659-660]. Но идея «рассадника» поддержана не была, и члены комиссии постановили замечания Успенского внести в журнал, а решение IV отдела оставить без изменений $[7$, т. 3, с. 660].

В материалах Предсоборного присутствия не оказалось подробного церковно-исторического обоснования возрождения чина диаконисс, а рассуждения епископа Кириона (Садзаглишвили) о наличии диаконисс в Грузинской Церкви не были подтверждены документально [7, т. 3, с. 21]. Историческую справку в докладной записке для отдела дает игуменья Екатерина (Ефимовская), ссылаясь на древние источники, апеллируя, правда, и к более раннему, чем византийский, периоду истории Церкви. Она утверждала, что «диакониссы причислялись к клиру» и поставлялись через рукоположение [4, РГИА, ф. 796, оп. 445, д. 340, л. 5], 15 правило Халкидонского собора она толкует именно как хиротонию диакониссы. По ее мнению, «в диакониссы посвящались лица, испытанные в нравственности и благочестии и для своего времени образованные, начитанные в Священном Писании и способные обучать истинам веры» [4, РГИА, ф. 796 , оп. 445 , д. 340 , л. 4-8], то есть нацеленные на катехизацию. В дальнейшем игуменья активно выступала в церковной печати, популяризуя опыт древних диаконисс в современных условиях, который возрождали монахини ее монастыря [6].

Результаты. Византийский чин диаконисс был тесно связан с развитием церковной жизни, когда женщины рукополагались по особому чину, сходному с диаконским, включались в число церковнослужителей, приписывались к приходам, могли обладать собственным имуществом, которое было ограждено императорским правом, помогали при крещении женщин, являлись участницами церковных чинопоследований, но самое главное - именно благодаря диакониссам сформировалось служение, позволявшее женщинам выполнять в Церкви институализированную деятельность. Важнейшими характеристиками диа- 


\section{ВИЗАНТИЙСКОЕ ПРАВОСЛАВИЕ}

конисс были возраст (не менее сорока лет) и строгое хранение целомудрия, что по сути сначала сближало (на это указывают «Новеллы» Юстиниана, в которых диакониссы и монахини упомянуты в одном ряду), а затем пусть и формально, но отождествляло их статус с монашеским: в поздневизантийской традиции руководительницы монастыря могли называться диакониссами, хотя таковыми уже не являлись. Ничего неизвестно о канонических запретах служения диаконисс в Византии, за исключением вышеупомянутого косвенного свидетельства Иоанна Мосха. Очевидно, исчезновение диаконисс было связано не с особой «нечистотой» женщин в определенные периоды и запретом в этой связи входить им в алтарь, как утверждал Вальсамон, a с естественным развитием жизни Церкви, уже не нуждавшейся в институциональном женском служении (например, помощь при крещении взрослых женщин). В свою очередь, развитие женского монашества давало женщинам возможность подвизаться в аскетическом образе жизни, который по статусу приписывался и диакониссам. Кроме того, диакониссы, будучи церковнослужительницами, имевшими епископское посвящение, в условиях церковных реалий византийского времени не могли быть включены в состав мужского клира (диакониссы в «Новеллах» Юстиниана стояли первыми в ряду других женщин, подвизавшихся в аскезе, но отдельно от клириков-мужчин), поэтому сохранение и развитие института диаконисс в эпоху позднего Средневековья становилось в принципе невозможным.

При попытках восстановить чин диаконисс на Предсоборном присутствии 1906 г. все его активные участники подчеркивали, что нужно возрождать женское институциональное служение в Церкви, но только ориентированное на социальную и катехизаторскую деятельность: диакониссы должны заботиться о больных и немощных, помогать священнику, следить за порядком в храме, заниматься религиозным просвещением, имея соответствующую подготовку. При том что возраст в сорок лет для посвящения диаконисс предполагалось оставить обязательным, а принятие монашеских обетов им не предписывалось. Статус женщин, несмотря на принятые правила, оставался недостаточно определенным, поскольку не было речи о собственно посвящении и внешнем одеянии (мафории с орарем) диаконисс, как в древние времена: например, епископ имел право посвятить женщину во время молебна, то есть уже не во время Литургии, о чем вполне определенно свидетельствовала рукопись Барберини, и не у престола в алтаре по Властарю и Вальсамону. Они не являлись монахинями, не включались в число клириков и даже не могли быть членами приходских советов. Функционал, который за ними оставался, был сходен с тем, чем занимались протестантские диакониссы (по сути, сестры милосердия), свечницы-уборщицы при храмах, учительницы, дававшие частные уроки (вопрос о преподавании диакониссами Закона Божьего даже в рамках воскресных школ не обсуждался). Предполагалось, что диакониссами должны были быть женщины, имевшие образование и достаточно активные в общественной жизни, однако парадокс состоял в том, что такие женщины после событий 1905-1906 гг. на практике свои усилия направляли не на благо, а на оппозиционную деятельность по отношению к Церкви и власти, и не могли быть реальными кандидатами на новую должность.

Таким образом, развитие чина диаконисс в Византии сделало вклад в развитие женского монашества, а попытки его восстановления в России к началу XX в. были связаны в большей степени с процессами, способствовавшими включению женщин в активную социальную деятельность. Кроме того, новое служение церковнослужительниц нуждалось в определенном статусе в уже сложившейся иерархии, однако данный вопрос на Предсоборном присутствии не обсуждался. Император Николай II в апреле 1907 г., когда революционные события завершились, принял решение Собор не созывать, а состоявшийся уже после его отречения Поместный собор 19171918 гг. также не принял никаких окончательных решений относительно восстановления чина диаконисс [2], так как попытки обновления внутрицерковной жизни были прерваны новыми революционными событиями. Исчезнувший в Византии чин диаконисс и попытка его восстановления в России показывают, что устойчивая институализация женского служе- 
ния произошла лишь в определенный период существования Церкви, имевшей в этом необходимость.

\section{ПРИМЕЧАНИЕ}

${ }^{1}$ Статья подготовлена в рамках проекта «База данных "Благотворительные учреждения Российской империи (1721-1917 гг.)"» при поддержке Фонда развития Православного Свято-Тихоновского гуманитарного университета. Автор выражает глубокую благодарность доценту ПСТГУ Елене Николаевне Козловцевой за отдельные предоставленные для статьи материалы.

\section{СПИСОК ЛИТЕРАТУРЫ}

1. Беляев, Д. Ф. Byzantina : Очерки, материалы и заметки по византийским древностям. Кн. 2 / Д. Ф. Беляев. - СПб. : Тип. имп. Акад. наук, 1893. $308 \mathrm{c}$.

2. Белякова, Е. В. Обсуждение вопроса о диакониссах на Поместном Соборе 1917-1918 гг. / Е. В. Белякова, Н. А. Белякова // Церковно-исторический вестник. - 2001. - № 8. - С. 139-161.

3. Белякова, Е. В. Женщина в православии: церковное право и российская практика / Е. В. Белякова, Н. А. Белякова, Н. А. Емченко. - М. : Кучково поле, 2011. - 704 c.

4. Докладная записка настоятельницы Леснинского женского монастыря близ гор. Белы Седлецкой губ. об основании при монастыре общины диаконисс для борьбы за укрепление пошатнувшегося авторитета Церкви // Российский государственный исторический архив (РГИА). - Ф. 796. Оп. 445. - Д. 340. - Л. 1-8 об.

5. Евхологий Барберини гр. 336 / изд. Е. Велковская, С. Паренти ; пер. С. Голованова. - Омск : Голованов, 2011. $-512 \mathrm{c}$.

6. Екатерина (Ефимовская), игум. Диакониссы первых веков христианства / игум. Екатерина (Ефимовская). - Сергиев Посад : Тип. Св.-Тр. Сергиевой лавры, 1909. - 50 с.

7. Журналы и протоколы заседаний высочайше учрежденного Предсоборного присутствия (1906 г.). Т. 1 / сост. свящ. И. Соловьев. - М. : Изд-во Новоспасского монастыря, 2014. - 896 с. ; Т. 2. 1088 c. ; T. 3. -1057 c.

8. Иоанн Мосх, блж. Луг духовный. - Сергиев Посад : Тип. Св.-Тр. Сергиевой лавры, 1896. - 282 с.

9. Макарий (Глухарев), архим. Мысли о способах к успешнейшему распространению христианской веры между евреями, магометанами и язычниками в Российской державе / архим. Мака- рий (Глухарев). - М. : Тип. А. И. Снегиревой, 1894. $-131 \mathrm{c}$.

10. Максимович, К. А. Церковные новеллы св. императора Юстиниана I (527-565) в современном русском переводе : Из опыта работы над проектом / К. А. Максимович // Вестник Православного СвятоТихоновского гуманитарного университета. Серия I: Богословие и философия. -2007. - Т. 1 (17). - С. 27-44.

11. Николай (Касаткин), свт. Дневники святого Николая Японского : в 5 т. Т. 2 / сост. К. Накамура. СПб. : Гиперион, 2004. - 880 с.

12. Правила святых поместных соборов с толкованиями. Т. 2. Вып. 2. - М. : Тип. Л. Ф. Снегирева, $1881 .-876 \mathrm{c}$.

13. С-ов [Скроботов, Н. А.]. Приходской священник Александр Васильевич Гумилевский / С-ов [Н. А. Скроботов]. - СПб. : Изд. А. Соколова, 1871.360 стб.

14. Служение женщин в Церкви : Исследования / отв. ред. С. Н. Баконина. - М. : Изд-во ПСТГУ, 2013. $-518 \mathrm{c}$.

15. Служение женщин в Церкви : Источники / сост. свящ. А. В. Постернак. - М. : Изд-во ПСТГУ, 2015. $-360 \mathrm{c}$.

16. Тафт, Р. Женщины в византийском храме: где, когда и почему? / Р. Тафт // Тафт, Р. Статьи. Т. 1 / Р. Тафт. - Омск : Голованов, 2010. - С. 86-195.

17. Троицкий, С.В.Диакониссы в Русской Церкви / С. В. Троицкий // Служение женщин в Церкви : Исследования / отв. ред. С. Н. Баконина. - М. : Изд-во ПСТГУ, 2013. - С. 303-334.

18. Abaelardus Petrus. Epistula ad Heloissam // Petri Abaelardi opera. Vol. 1 / ed. V. Cousin. - Paris : A. Durand, 1849. - 754 p.

19. Athanasius Scholasticus. Novellae constitutiones // Das Novellensyntagma des Athanasios von Emesa / eds. D. Simon, S. Troianos. - Frankfurt am Main : Löwenklau Gesellschaft, 1989. - 512 p.

20. Balsamon Theodorus. Commentaria in canones XXX sanctae et oecumenicae quartae Synodi Chalcedonensis // Theodori Balsamonis patriarchae Theopolis Magnae Antiochiae opera. T. I / ed. J.-P. Migne. - Paris : J.-P. Migne, 1865. - Col. 381498. - (Patrologia Graeca ; T. 137).

21. Balsamon Theodorus. Responsa ad interrogationes Marci // Theodori Balsamonis patriarchae Theopolis Magnae Antiochiae opera. T. II / ed. J.-P. Migne - Paris : J.-P. Migne, 1865. - Col. 9511012. - (Patrologia Graeca ; T. 138).

22. Basilicorum libri LX. Vol. 1 / eds. H.J. Scheltema, N. van der Wal. - Groningen : Wolters, 1955. - 438 p.

23. Blastares Mattheus. Syntagma alphabeticum rerum omnium // Georgii Pachymerae opera omnia. T. 2: accedit Matthaei Blastaris syntagma canonum / ed. J.-P. Migne. - Paris : J.-P. Migne, 1865. Col. 959-1400. - (Patrologia Graeca; T. 144). 


\section{ВИЗАНТИЙСКОЕ ПРАВОСЛАВИЕ}

24. Constantinus VII Porphirogenitus. De cerimoniis aulae Byzantinae $=$ Le livre des ceremonies . Vol. 1 / éd. A. Vogt. - Paris : Les Belles Lettres, 1935. $750 \mathrm{p}$.

25. Corpus iuris civilis. Vol. 3. Novellae / eds. R. Schoell, G. Kroll. - Berolini : P. Krueger, 1904. -810 p.

26. Didascalia et constitutiones apostolorum. Vol. 1 / ed. F. X. Funk. - Paderbornae : F. Schoeningh, 1905. - 704 p. ; Vol. 2. - 208 p.

27. Karras, V. A. Female Deacons in the Byzantine Church / V. A. Karras // Church History. - 2004. Vol. 73 (2). - P. 272-316. - DOI: https://doi.org/10. 1017/S000964070010928X.

28. Karras, V. A. Women in the Byzantine Liturgy / V. A. Karras. - Oxford : Oxford University Press, 2005. $208 \mathrm{p}$.

29. Les Constitutions apostoliques. Vol. 1 (I-II) / éd B.M. Metzger. - Paris : Éditions du Cerf, 1985. 356 p.; Vol. 2(III-VI). - 1986. -424 p.; Vol. 3(VII-VIII). 1987. -360 p. - (Sources chrétiennes 320, 329, 336).

30. Moschus Iohannus. Pratum spirituale // Procopii Gazaei, Christiani rhetoris et hermeneutae, opera. T. 3 / ed. J.-P. Migne. - Paris : J.-P. Migne, 1863. Col. 2851-3116. - (Patrologia Graeca ; T. 87, Pars. 3).

31. Photius. Syntagma canonum // Photii, Constantinopolitani patriarchae, opera omnia. T. 4 / ed. J.-P. Migne. - Paris: J.-P. Migne, 1860. - Col. 441975. - (Patrologia Graeca ; T. 104).

32. Prochiron auctum // Prochiron auctum : Meditatio de nudis pactis, Michaelis Pselli Synopsis legum, Michaelis Attaliotae opus de jure, XXVI decisiones Demetrii Chomatiani / eds. P.I. Zepos, I.D. Zepos. - Athens : Fexis, 1931. - P. 1-106. - (Jus Graecoromanum; vol. 7).

33. Pseudo-Codinus. Patria Constantinopoleos // Scriptores originum Constantinopolitarum / ed. T. Preger. - Leipzig : Teubner, 1907. - 376 p.

34. Saint Basile. Lettres. Vol. 2 / ed. Y. Courtonne. Paris : Les Belles Lettres, 1961. - 221 p.

35. Theodoru, E. Berümte Diakonissen der byzantinischen Zeit / E. Theodoru // Diakonat und Diakonie in frühchristlicher und ostkirchlicher Tradition / hrsg. A. Jensen, G. Larentzakis. - Graz : Institut für Ökumenische Theologie, 2008. - S. 135-152.

36. Theodosiani libri XVI cum constitutionibus sirmondianis et leges novellae ad theodosianum pertinentes. Vol. 1, Pars 2 / eds. T. Mommsen, P. Meyer. Berolini : Weidmannos, 1905.-332 p.

37. Typicon monasterii Theotoci Bebaias Elpidos // Deux typica byzantins de l'époque des Paléologues / éd. H. Delehaye. - Bruxelles : Akadémie Royale de Belgique, 1921. - P. 18-95.

38. Vita S. Olympiadis et narratio Sergiae de eiusdem translatione // Analecta Bollandiana. T. 15 / eds. C. de Smed et al. - Bruxelles : Société des Bollandistes, 1896. - P. 400-423.
39. Wijngaards, J. No Women in Holy Orders? The Women Deacons of the Early Church / J. Wijngaards. Norwich : Canterbury Press, 2002. - 222 p.

40. Wirth, P. Zur Geschichte des Diakonats an der Hagia Sophia / P. Wirth // Polychronion: Festschrift Franz Dölger zum 75. Geburtstag / hrsg. P. Wirth. Heidelberg : C. Winter, 1966. - S. 380-382.

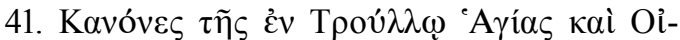

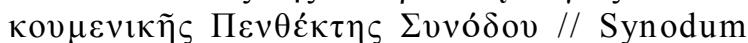
Constantinopolitanus Canones // Documenta Catholica omnia. $-\Sigma$. 1-23. - Electronic text data. Mode of access: http://www.documentacatholicaomnia. eu/03d/0691-0691,_Synodum_Constantinopolitanum, Canones, GR.pdf(date of access: 23.12.2020). - Title from screen.

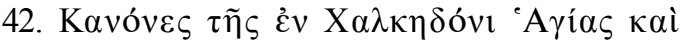

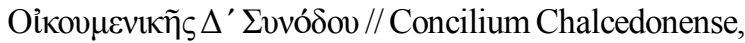
Documenta omnia // Documenta Catholica omnia. 5. 1-6. - Electronic text data. - Mode of access: https:// www.documentacatholicaomnia.eu/03d/0451-0451, Concilium_Chalcedonense,_Documenta_Omnia,_GR.pdf (date of access: 23.12.2020). - Title from screen.

\section{REFERENCES}

1. Belyaev D.F. Byzantina: Ocherki, materialy i zametki po vizantiyskim drevnostyam [Byzantina: Essays, Materials and Notes on Byzantine Antiquities]. Saint Petersburg, Tipografiya imperatorskoy Akademii nauk, 1893, book 2. 308 p.

2. Belyakova E.V., Belyakova N.A. Obsuzhdenie voprosa o diakonissakh na Pomestnom Sobore 1917$1918 \mathrm{gg}$. [Discussion of the Issue of Deaconesses at the Local Council of 1917-1918]. Tserkovnoistoricheskiy vestnik [Church and Historical Bulletin], 2001, no. 8, pp. 139-161.

3. Belyakova E.V., Belyakova N.A., EmchenkoN.A. Zhenshchina $v$ pravoslavii: cerkovnoe pravo $i$ rossiyskaya praktika [Woman in the Orthodox Church: Canon Law and Russian Practice]. Moscow, Kuchkovo pole Publ., 2011. 704 p.

4. Dokladnaya zapiska nastoyatelnitsy Lesninskogo zhenskogo monastyrya bliz gor. Bely Sedletskoy gub. ob osnovanii pri monastyre obshchiny diakoniss dlya borby za ukreplenie poshatnuvshegosya avtoriteta Tserkvi [A Memo from the Mother Superior of the Lesna Convent of $\mathrm{Bia}^{3} \mathrm{a}$, Siedlce Governorate on the Establishment of a Community of Deaconesses at the Monastery to Fight for the Strengthening of the Shaken Authority of the Church]. Rossiyskiy gosudarstvennyy istoricheskiy arkhiv (RGIA) [Russian State Historical Archive(RSHA)], f. 796, inv. 445, d. 340, 1. 1-8 sq.

5. Velkovskaya E., Parenti S., Golovanov S., ed. Evkhologiy Barberini gr. 336 [Euchologion Barberini gr. 336]. Omsk, Golovanov Publ., 2011. 512 p. 
6. Ekaterina (Efimovskaya), hegumen. Diakonissy pervykh vekov khristianstva [Deaconesses of the First Centuries of Christianity]. Sergiev Posad, Tipografiya Svyato-Troitskoy Sergievoy Lavry, 1909. 50 p.

7. Solovev I., priest, ed. Zhurnaly i protokoly zasedaniy vysochaishe uchrezhdennogo Predsobornogo prisutstviya (1906 g.) [Logs and Minutes of Meetings of the Most Highly Established Pre-Council Conference (1906)]. Moscow, Izd-vo Novospasskogo monastyrya, 2014, vol. 1. 896 p.; vol. 2. 1088 p.; vol. 3. 1057 p.

8. Ioann Moskh, blessed. Lug dukhovnyy [Spiritual Meadow]. Sergiev Posad, Tipografiya Svyato-Troitskoy Sergievoy Lavry, 1896. 282 p.

9. Makariy (Glukharev), archimandrite. Myslio sposobakh $k$ uspeshneyshemu rasprostraneniyu khristianskoy very mezhdu evreyami, magometanami i yazychnikami v Rossiyskoy derzhave [Thoughts on Ways to Successfully Spread the Christian Faith Among Jews, Mohammedans and Pagans in the Russian State]. Moscow, Tipografiya A.I. Snegirevoy, 1894. $131 \mathrm{p}$.

10. Maksimovich K.A. Tserkovnye novelly sv. imperatora Yustiniana I (527-565) v sovremennom russkom perevode: Iz opyta raboty nad proektom [Church Novellas of St. Emperor Justinian I (527-565) in Modern Russian Translation: From the Experience of Working on the Project]. Vestnik Pravoslavnogo Svyato-Tikhonovskogo gumanitarnogo universiteta. Seriya I: Bogoslovie i filosofiya [St. Tikhons University Review. Series I: Theology and Philosophy], 2007, vol. 1 (17), pp. 27-44.

11. Nakamura K., ed. Nikolay (Kasatkin), svt. Dnevniki svyatogo Nikolaya Yaponskogo: $v 5 t$. [Diaries of St. Nicholas of Japan. In 5 Vols.]. Sankt Peterburg, Giperion Publ., 2004, vol. 2. 880 p.

12. Pravila svyatykh pomestnykh soborov s tolkovaniyami [Rules of the Holy Local Councils with Interpretations]. Moscow, Tipografiya L.F. Snegireva, 1881, vol. 2, iss. 2.876 p.

13. S-ov (Skrobotov N.À.). Prikhodskoy svyashchennik Aleksandr Vasilevich Gumilevskiy [Parish Priest Alexandr Vasilevich Gumilevskij]. Sankt Petersburg, Izdatelstvo A. Sokolova, 1871. 360 cols.

14. Bakonina S.N., ed. Sluzhenie zhenshchin v Tserkvi: Issledovaniya [Womens Ministry in the Church: Researches]. Moscow, Izd-vo PSTGU, 2013. 518 p.

15. PosternakA.V., priest, ed. Sluzhenie zhenshchin v Tserkvi: Istochniki [Womens Ministry in the Church: Sources]. Moscow, Izd-vo PSTGU, 2015.360 p.

16. Taft R. Zhenshchiny v vizantiyskom khrame: gde, kogda i pochemu? [Women at Church in Byzantium: Where, When - and Why?]. Taft R. Statii [Articles]. Omsk, Golovanov Publ., 2010, vol. 1, pp. 86-195.

17. Troitskiy S.V. Diakonissy v Russkoy Tserkvi [Deaconesses in the Russian Church]. Bakonina S.N., ed. Sluzhenie zhenshchin v Tserkvi: Issledovaniya [Womens Ministry in the Church: Researches]. Moscow, Izd-vo PSTGU, 2013, pp. 303-334.

18. Abaelardus Petrus. Epistula ad Heloissam. Cousin V., ed. Petri Abaelardi opera. Vol. 1. Paris, A. Durand, 1849. 754 p.

19. Athanasius Scholasticus. Novellae constitutiones. Simon D., Troianos S., eds. Das Novellensyntagma des Athanasios von Emesa. Frankfurt am Main, Löwenklau Gesellschaft, 1989.512 p.

20. Balsamon Theodorus. Commentaria in canones XXX sanctae et oecumenicae quartae Synodi Chalcedonensis. Migne J.-P., ed. Theodori Balsamonis patriarchae Theopolis Magnae Antiochiae opera. T. I. Paris, J.-P. Migne, 1865, cols. 381-498. (Patrologia Graeca; t. 137).

21. Balsamon Theodorus. Responsa ad interrogationes Marci. Migne J.-P., ed. Theodori Balsamonis patriarchae Theopolis Magnae Antiochiae opera. T. II. Paris, J.-P. Migne, 1865, cols. 951012. (Patrologia Graeca; t. 138).

22. Scheltema H.J., van der Wal N., eds. Basilicorum libri LX. Vol. 1. Groningen, Wolters, 1955.438 p.

23. Blastares Mattheus. Syntagma alphabeticum rerum omnium. Migne J.-P., ed. Georgii Pachymerae opera omnia. T. 2: accedit Matthaei Blastaris syntagma canonum. Paris, J.-P. Migne, 1865, cols. 9591400. (Patrologia Graeca; t. 144).

24. Vogt A., éd. Constantinus VII Porphirogenitus. De cerimoniis aulae Byzantinae = Le livre des ceremonies. Vol. 1. Paris, Les Belles Lettres, 1935. 750 p.

25. Schoell R., Kroll G., eds. Corpus iuris civilis. Vol. 3. Novellae. Berolini, P. Krueger, 1904. 810 p.

26. Funk F.X., ed. Didascalia et constitutiones apostolorum. Paderbornae, F. Schoeningh, 1905, vol. 1.704 p.; vol. 2. 208 p.

27. Karras V.A. Female Deacons in the Byzantine Church. Church History, 2004, vol. 73 (2), pp. 272-316. DOI: https://doi.org/10.1017/S000964070010928X.

28. Karras V.A. Women in the Byzantine Liturgy. Oxford, Oxford University Press, 2005. 208 p.

29. Metzger B.M., ed. Les Constitutions apostoliques. Paris, Éditions du Cerf. Vol. 1 (I-II). 1985. 356 p.; vol. 2 (IIIVI). 1986. 424 p.; vol.3(VII-VIII). 1987.360p.

30. Moschus Iohannus. Pratum spirituale. Migne J.-P., ed. Procopii Gazaei, Christiani rhetoris et hermeneutae, opera. T. 3. Paris, J.-P. Migne, 1863, cols. 2851-3116. (Patrologia Graeca; t. 87, pars. 3).

31. Photius. Syntagma canonum. Migne J.-P., ed. Photii, Constantinopolitani patriarchae, opera omnia. T. 4. Paris, J.-P. Migne, 1860, cols. 441-975. (Patrologia Graeca; t. 104).

32. Zepos P.I., Zepos I.D., eds. Prochiron auctum. Prochiron auctum: Meditatio de nudis pactis, Michaelis Pselli Synopsis legum, Michaelis Attaliotae opus de jure, XXVI decisiones Demetrii 


\section{ВИЗАНТИЙСКОЕ ПРАВОСЛАВИЕ}

Chomatiani. Athens, Fexis, 1931, pp. 1-106. (Jus Graecoromanum; vol. 7).

33. Pseudo-Codinus. Patria Constantinopoleos. Preger T., ed. Scriptores originum Constantinopolitarum. Leipzig, Teubner, 1907.376 p.

34. Courtonne Y., ed. Saint Basile. Lettres. Paris, Les Belles Lettres, 1961, vol. 2. 221 p.

35. Theodoru E. Berümte Diakonissen der byzantinischen Zeit. Jensen A., Larentzakis G., hrsg. Diakonat und Diakonie in frühchristlicher und ostkirchlicher Tradition. Graz, Institut für Ökumenische Theologie, 2008, S. 135-152.

36. Mommsen T., Meyer P., eds. Theodosiani libri XVI cum constitutionibus sirmondianis et leges novellae ad theodosianum pertinentes. Vol. 1, Pars 2. Berolini, Weidmannos, 1905. $332 \mathrm{p}$.

37. Typicon monasterii Theotoci Bebaias Elpidos. Delehaye H., ed. Deux typica byzantins de lépoque des Paléologues. Brussels, Akadémie Royale de Belgique, 1921, pp. 18-95.

38. Vita S. Olympiadis et narratio Sergiae de eiusdem translatione. Smed C. de et al, eds. Analecta Bollandiana. T. 15. Brussels, Société des Bollandistes, 1896, pp. 400-423.
39. Wijngaards J. No Women in Holy Orders? The Women Deacons of the Early Church. Norwich, Canterbury Press, 2002. 222 p.

40. Wirth P. Zur Geschichte des Diakonats an der Hagia Sophia. Wirth P., hrsg. Polychronion: Festschrift Franz Dölger zum 75. Geburtstag. Heidelberg, C. Winter, 1966, S. 380-382.

41. Kanones tēs en Troullō Agias kai Oikoumenikēs Penthektēs Synodou [Canons of the Holy and Ecumenical Fifth-Sixth Council in Trullo]. Synodum Constantinopolitanus Canones. Documenta Catholica omnia, pp. 1-23. URL: http:// www.documentacatholicaomnia.eu/03d/0691 0691,_Synodum_Constantinopolitanum,_Canones,_GR.pdf (accessed 23 December 2020).

42. Kanones tēs en Chalkēdoni Agias kai Oikoumenikēs D' Synodou [Canons of the Holy and Ecumenical Fourth Council in Chalcedon]. Concilium Chalcedonense, Documenta omnia. Documenta Catholica omnia, pp. 1-6. URL: https://www. documentacatholicaomnia.eu/03d/0451-0451, Concilium Chalcedonense, Documenta_Omnia,_GR.pdf (accessed 23 December 2020).

\section{Information About the Author}

Andrey V. Posternak, Candidate of Sciences (History), Associate Professor, Dean of the Faculty of History and Philology, St. Tikhon's Orthodox University, Ilovaiskaya St, 9, Bld. 2, 109651 Moscow, Russian Federation, posternakav@inbox.ru, https://orcid.org/0000-0003-1310-3503

\section{Информация об авторе}

Андрей Владимирович Постернак, кандидат исторических наук, доцент, декан историко-филологического факультета, Православный Свято-Тихоновский гуманитарный университет, ул. Иловайская, 9, стр. 2, 109651 г. Москва, Российская Федерация, posternakav@inbox.ru, https://orcid.org/0000-0003-1310-3503 